\title{
Performance of electrical stimulated anaerobic baffled reactor for removal of typical pollutants from low-strength municipal wastewater at low temperatures
}

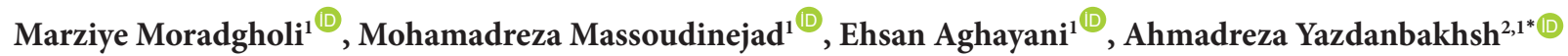 \\ ${ }^{1}$ Departement of Environmental Health Engineering, School of Public Health and Safety, Shahid Beheshti University of Medical \\ Sciences, Tehran, Iran \\ ${ }^{2}$ Workplace Health Promotion Research Center, Shahid Beheshti University of Medical Sciences, Tehran, Iran
}

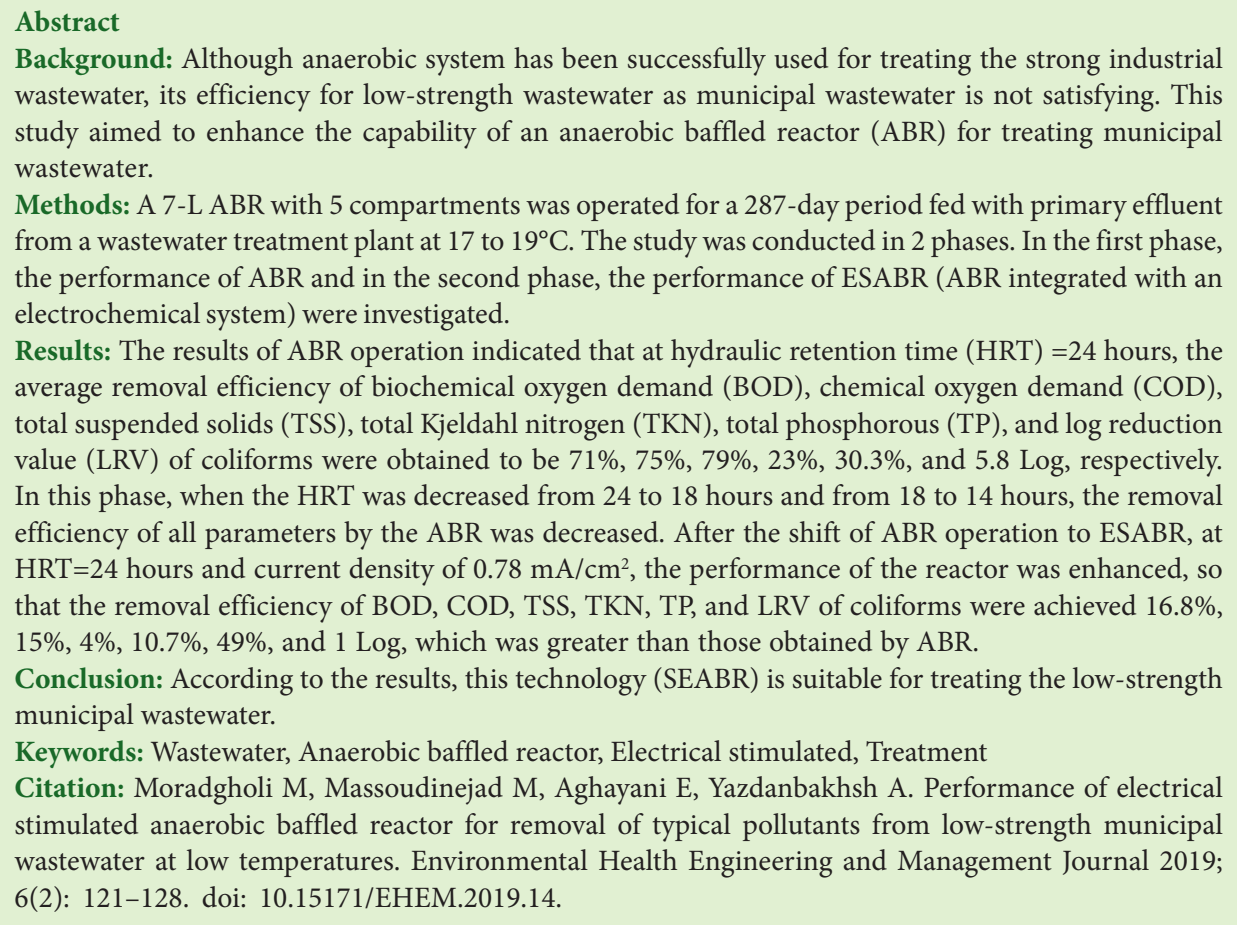

\section{Article History:}

Received: 29 January 2019

Accepted: 7 May 2019

ePublished: 19 May 2019

\section{Introduction}

Currently, aerobic processes are widely used for municipal wastewater treatment. Despite the advantages of aerobic treatment of municipal wastewater like high efficiency, reduced odor, nitrification of ammonia, and reduction of greenhouse gases compared to anaerobic treatment, disadvantages of this method include high capital cost for aeration equipment, high operating cost, high maintenance requirements, large amounts of excess sludge production, and more nutrients required, which make this process costly. So anaerobic process seems to be an attractive alternative for the treatment of municipal wastewater, especially due to economic advantages over aerobic process (1-3).

Since the performance of the conventional low-rate anaerobic system like septic and Imhoff tanks is not sufficient for domestic wastewater treatment, therefore, the use of new high-rate anaerobic reactors has been investigated. In the last decade, new high-rate anaerobic reactors, such as upflow anaerobic sludge blanket (UASB), anaerobic filter (AF), anaerobic fluidized bed, anaerobic expanded bed reactors, and anaerobic baffled reactors (ABRs) have been developed. In high-rate anaerobic reactors, the separation between the hydraulic retention time (HRT) and the solids retention time is achievable. Such a separation allows the slow-growing 
microorganisms to remain within the reactor independent of wastewater flow, thereby, allowing significantly higher efficiency for the treatment of high-strength wastewaters. Also, these reactors allow the treatment of low- or medium-strength wastewaters such as municipal wastewater $(1,4,5)$. Many studies have been conducted on domestic wastewater treatment using different types of high-rate anaerobic reactors (4-13). Up to now, most experiments for anaerobic treatment of municipal or lowstrength wastewaters have been conducted on the UASB and $\mathrm{ABR}(2,8,10,13-15)$. Among these two reactors, $\mathrm{ABR}$ is more widely used due to its attractive aspects including simplicity, low investment and operation cost, and its ability to separate suspended growth acidogenesis and methanogenesis down the reactor, allowing the reactor to behave as a two-phase system $(16,17)$.

$\mathrm{ABR}$ is a multi-compartments reactor with a series of baffles in which the liquid is forced to flow up and down from one compartment to the next. High concentrations of biomass retain in each compartment, so the contact between wastewater and biomass is improved.

Many studies used ABR for treating municipal or lowstrength synthetic wastewater in the ABR (18-20). The results of studies have shown that despite the advantages of the ABR, the efficiency of this reactor like other anaerobic system for treating the municipal wastewater is not enough to meet the effluent standards of contaminants, especially at low or ambient temperature.

To achieve better performance of ABR for the treatment of municipal wastewater at ambient temperature, some modifications of ABR have been employed, including: 9chamber modified ABR in three parallel sets (14), ABR with media (2), bamboo carrier ABR (15), granular-bed ABR (13), and electrochemical ABR (21).

In the recent years, one of the processes that is integrated by aerobic/anaerobic biological systems is electrochemistry named bioelectrochemical systems (BESs). In this process, two targets might be expected: electricity generation via microbial fuel cell or methane/hydrogen production via microbial electrolysis cell (MEC). Up to now, most studies have been conducted on BES, focused on electricity or hydrogen/methane gas generation and there are few studies on the performance of these systems for the contaminants removal (21-24). On the other hand, as noted above, the application of aerobic system for the treatment of municipal wastewater is very costly in both low and large communities. So, the focus of this study was on the effects of the electrochemical reaction on the performance of ABR (as a simple and low cost technology) for the municipal wastewater treatment at low temperatures.

\section{Materials and Methods}

Chemicals and analysis

All chemical reagents were analytical grade and used without further purification. Chemicals were purchased from Sigma-Aldrich (USA), Merck (Germany), and BDH (England). In all stages of the experiments, the influent and effluent samples were taken and measured every 3 to 7 days for the main parameters including biochemical oxygen demand (BOD), chemical oxygen demand (COD), total suspended solids (TSS), total Kjeldahl nitrogen (TKN), total phosphorous (TP), and total coliform bacteria. Meanwhile, the operating parameters, such as $\mathrm{pH}$, alkalinity, and temperature were analyzed continuously during the study. All experiments were determined by standard methods (25). BOD samples were measured by respirometric Oxitop TS 606 G/2 WTW with WTW incubator. The COD test was done by closed refluxtitrimetric method. TSS was measured by gravimetric method. VAPODEST digestion system made by Gerhardt Company was used for TKN analysis. The acidic digestion vanadomolybdophosphoric acid method was used to determine the TP. Temperature and $\mathrm{pH}$ of the wastewater were measured by the Corning $\mathrm{pH}$ meter includes $\mathrm{pH}$ and temperature electrodes. Also, the diurnal temperature of the pilot room beside the reactor was measured by a digital electrode thermometer. Total coliforms were measured by the most probable number (MPN). Gas production by gram-negative, non-spore-forming, and rod-shaped bacteria was considered as a positive coliform reaction within 24 to 48 hours at $35 \pm 0.5^{\circ} \mathrm{C}$.

Reactor configuration, startup and procedure

A bench scale ABR consisted of five equal size chambers, with external dimensions of L50 $\times \mathrm{W} 15 \times \mathrm{H} 18 \mathrm{~cm}$, and effective liquid volume of $7 \mathrm{~L}$ was constructed with Plexiglas sheet and installed in the pilot room (Figure 1). Each compartment of ABR was separated into two parts of up-flow and down-flow by a vertical baffle. Baffles were installed with a $2 \mathrm{~cm}$ distance from the bottom of the reactor. To compare the effect of electrical stimulation on the performance of the ABR reactor, in the first stage of the study, the reactor was considered as the blank reactor that was operated without electrochemical system, and in the second stage, the reactor was integrated with an

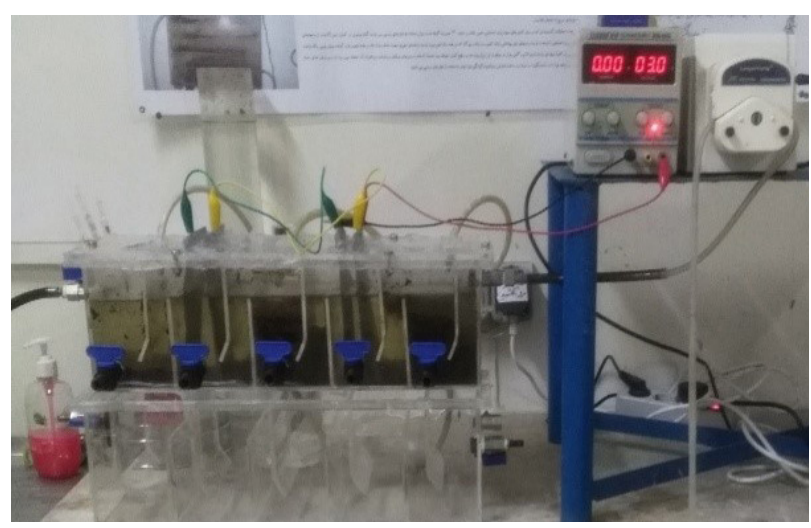

Figure 1. ABR/ESABR used in this study. 
electrochemical system and named electrically-stimulated reactor (ESABR). Electrochemical system composed of two paired steel mesh plate-type electrodes $(8 \mathrm{~cm} \times 16$ $\mathrm{cm} \times 2 \mathrm{~mm}$ ) that were installed in the second and fourth compartments of the ESABR. The distance between two electrodes were $1 \mathrm{~cm}$ and they were powered by a DC power supply. Temperature of the pilot room was controlled by an air handling unit at $20 \pm 4^{\circ} \mathrm{C}$. The daily average temperature of the pilot room was recorded.

For feeding the reactor, wastewater was taken from Shahrak-e-Gharb wastewater treatment plant. This municipal wastewater treatment plant is located in the west of Tehran, the capital city of Iran. Wastewater was directly taken from the end of the primary sedimentation tank prior to biological treatment. The reactor was seeded with the sludge from an operating UASB, treating dairy wastewater. This sludge contained $25.2 \mathrm{~g} / \mathrm{L}$ total suspended solids and $15.8 \mathrm{~g} / \mathrm{L}$ total volatile solids. After seeding, the reactor was fed continuously with wastewater by a peristaltic pump (Longer pump YZ1515x). This study was done in three experimental runs for 287 days. In the first run, startup and the steady-state performance of $\mathrm{ABR}$ was evaluated at HRT $=24$ hours. In the second experimental run, the performance of ABR was evaluated at HRTs of $24,18,14$ hours. In the third run of the study, the performance of ESABR was evaluated at $\mathrm{HRT}=24 \mathrm{~h}$. In ESABR, the energy consumption value was calculated using Eq. (1).

$$
\mathrm{E}\left(\mathrm{kWh} / \mathrm{m}^{3}\right)=\frac{\mathrm{U}(\mathrm{v}) \cdot \mathrm{I}(\mathrm{A}) \cdot \mathrm{t}(\mathrm{h})}{\mathrm{V}(\mathrm{L})}
$$

Where 1, U, I, t, and V are voltage, current, reaction time, and volume of wastewater in reactor, respectively.

\section{Results}

Composition of wastewater

The average values of the settled wastewater constituents used in the study are presented in Table 1.

According to the concentration of COD, $\mathrm{BOD}_{5}$, and TSS of the primary effluent of municipal wastewater, weak municipal wastewater was fed to the ABR in this study (Table 1).

\section{Temperature variation}

The variation and trends of daily mean temperature of the influent wastewater and the pilot room during the operation were presented in Figure 2. The averages and standard deviations of the influent wastewater and pilot room temperatures were $17.7 \pm 0.76$ and $16.8 \pm 0.68^{\circ} \mathrm{C}$, respectively.

\section{ABR startup and performance at different HRTs}

To startup the ABR, the primary effluent municipal wastewater was continuously fed to the reactor at $\mathrm{HRT}=24$ hours. The performance of the reactor for COD and BOD removal is shown in Figure 3. As presented in Figure 4,
Table 1. The average values of constituents of the municipal wastewater (primary effluent)

\begin{tabular}{lcc}
\hline Constituents & Unit & Value (mean \pm SD) \\
\hline $\mathrm{BOD}_{5}$ & $\mathrm{mg} / \mathrm{L}$ & $160 \pm 10$ \\
$\mathrm{COD}$ & $\mathrm{mg} / \mathrm{L}$ & $280 \pm 20$ \\
$\mathrm{TSS}$ & $\mathrm{mg} / \mathrm{L}$ & $160 \pm 17$ \\
$\mathrm{TP}$ & $\mathrm{mg} / \mathrm{L}$ & $6 \pm 2$ \\
TKN & $\mathrm{mg} / \mathrm{L}$ & $85 \pm 10$ \\
\hline Total alkalinity & $\mathrm{mg} / \mathrm{L} \mathrm{CaCo3}$ & $320 \pm 20$ \\
$\mathrm{pH}$ & & $7.6-8.8$ \\
\hline Temperature & ${ }^{\circ} \mathrm{C}$ & $17.7 \pm 0.76$ \\
\hline Total coliforms & $\mathrm{MPN} / 100 \mathrm{~mL}$ & $5 \times 10^{8}$ \\
\hline
\end{tabular}

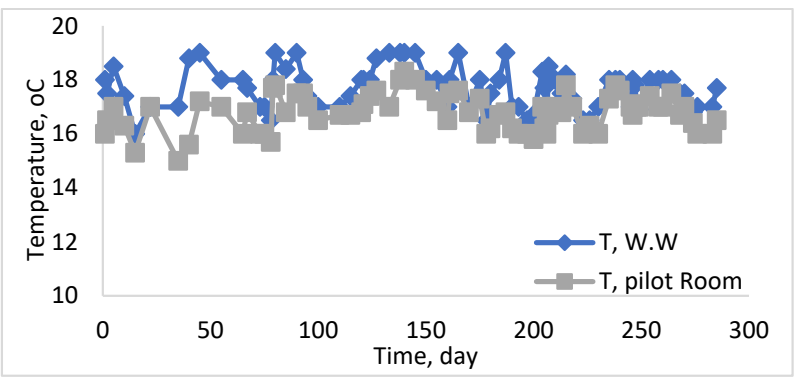

Figure 2. Temperature variation of wastewater and pilot room during the operation of $A B R$ and ESABR.

the steady-state performance was achieved on day 70 . The average removal of BOD and COD on steady state condition from day 70 to 80 was obtained to be 71 and $75 \%$, respectively.

From day 130 to 165 , the HRT changed to 18 hours, and from day 166 to 205 , it changed to 14 hours, respectively. Figure 4 represents the profiles of BOD, COD, and TSS at HRTs of 24,18 , and 14 hours. As shown in this figure, at the beginning of each HRT, some fluctuations were occurred but after few days, the ABR approached a steady state. At HRTs of 24, 18, and 14 hours following steady state, the performance of ABR for COD, BOD, TSS, TKN, TP removal, and log reduction value (LRV) of total coliforms bacteria were determined. The percent removal efficiency of parameters at HRTs of 24, 18, and 14 are presented in

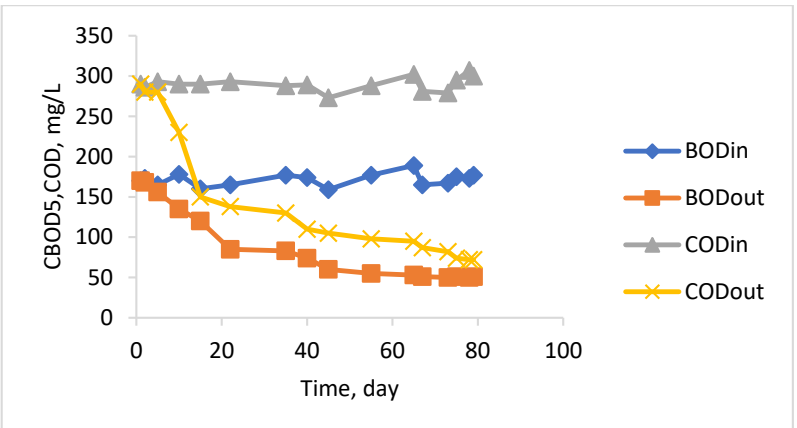

Figure 3. Variation of $B O D$ and $C O D$ in the influent and effluent during the startup of $A B R(H R T=24 h)$. 
Figure 5. As shown in Figure 5, the maximum removal of TSS, BOD, COD, TKN, and P removal were achieved at HRT of 24 hours with average removal of $80,74,77,23$, and $30 \%$, respectively.

In Figure 6, the efficiency of ABR for removal of coliform bacteria is presented. As shown in this figure, the LRV of coliform bacteria was achieved 5.8 at HRT $=24 \mathrm{~h}$ hours.

\section{Performance of ESABR}

From day 206 to 226, HRT of ABR was changed from 14 h to 24 hours, again on day 227, the reactor was shifted to ESABR as described before. In this stage, the ESABR was operated at four current densities $(0.195,0.39,0.78$, and $1.15 \mathrm{~mA} / \mathrm{cm}^{2}$ ). The performance results of ESABR for the removal of BOD, COD, TSS, TKN, TP, and total coliforms are presented in Figures 7 to 9. As illustrated in these figures, the maximum removal of all parameters was obtained to be $0.78 \mathrm{~mA} / \mathrm{cm}^{2}$ by ESABR

The concentration of contaminants in the effluent of $A B R$ and SEABR are presented and compares to discharge effluent standards in Table 2. As shown in this table, except nitrogen, other measured parameters conform the standards of effluent discharge to surface water established

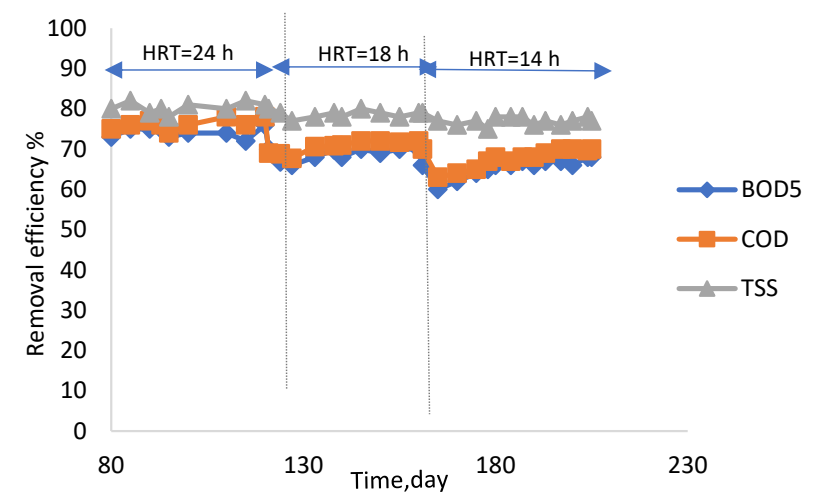

Figure 4. Variation of percent removal efficiency of BOD, COD, and TSS by $A B R$ at various HRTs.

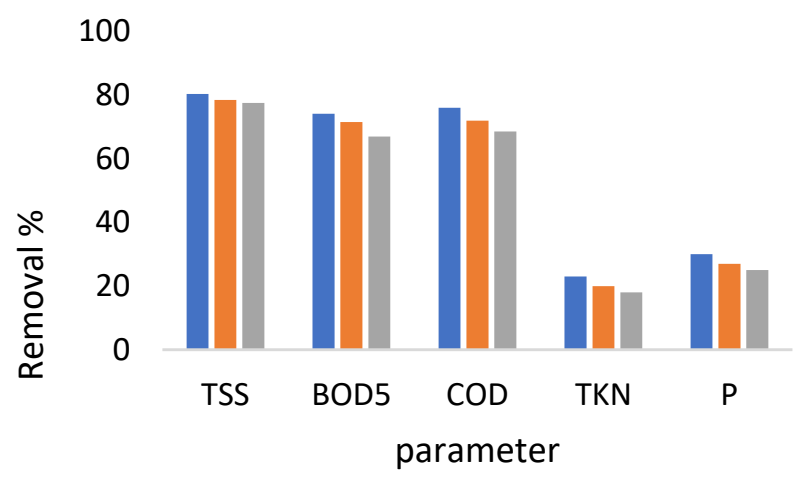

- HRT $=24 \mathrm{~h} \quad \mathrm{HRT}=18 \mathrm{~h} \quad \mathrm{HRT}=14 \mathrm{~h}$

Figure 5. Comparison of the performance of $A B R$ for removal of $B O D$, COD, and TSS at various HRTs. by the Iran's Environment Protection Organization (IEPO).

In the optimum performance of ESABR, with current density $=0.78 \mathrm{~mA} / \mathrm{cm}^{2}$, voltage $=0.6 \mathrm{~V}$, current $=0.2 \mathrm{~A}$, $\mathrm{HRT}=24$ hours, and volume of wastewater $=7 \mathrm{~L}$, the energy consumption was achieved $0.41 \mathrm{kWh} / \mathrm{m}^{3}$.

Discussion

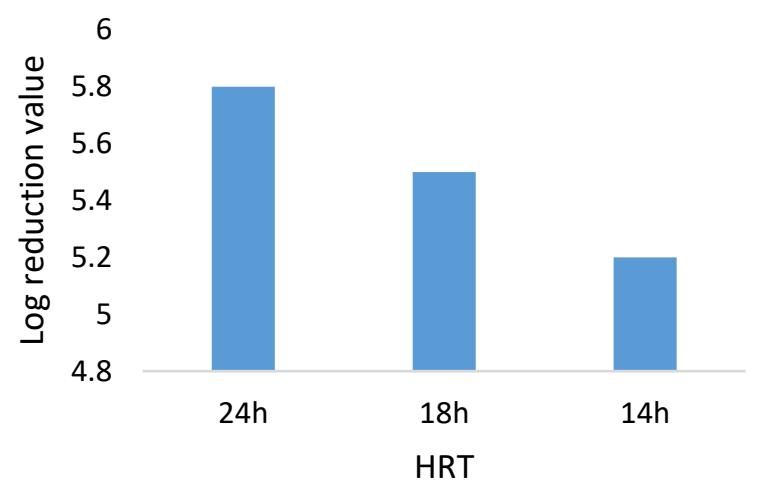

Figure 6. Comparison the performance of $A B R$ for removal of T. Coliforms at various HRTs.

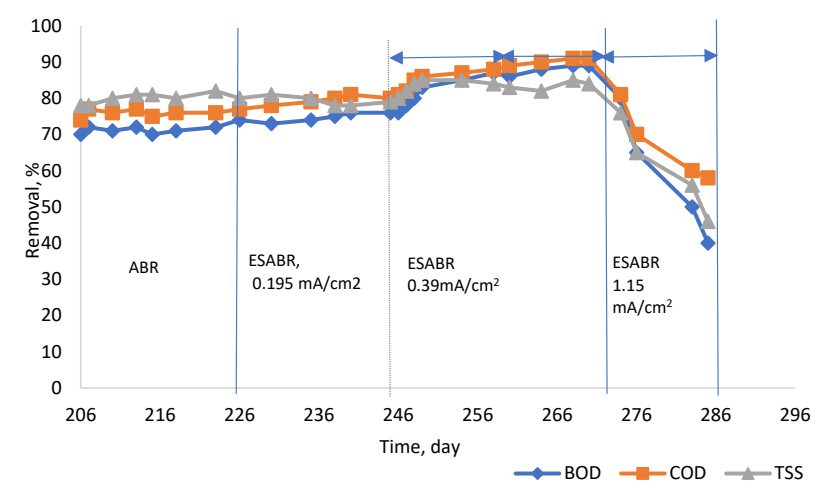

Figure 7. Variations of percent removal of BOD, COD, and TSS by ABR and ESABR (with different current densities) at HRT=24 h.

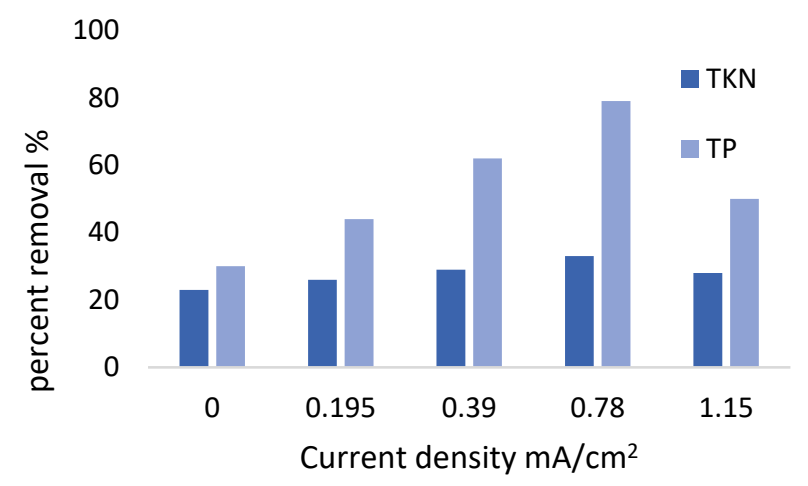

Figure 8. Comparison of the performance of $A B R$ and ESABR for removal of TKN and TP at HRT=24. 


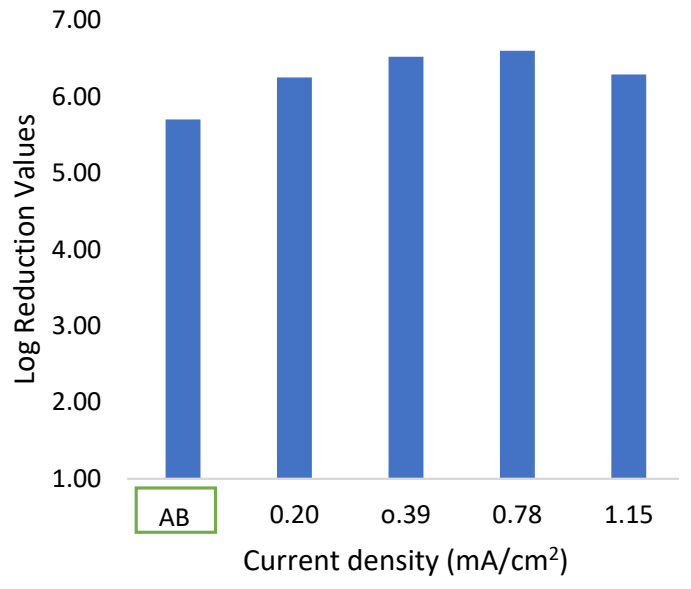

Figure 9. Comparison of the performance of $A B R$ and ESABR for removal of total coliforms at $\mathrm{HRT}=24 \mathrm{~h}$.

\section{ABR start up and performance}

As shown in Figure 3, at HRT $=24$ hours, the steady state of ABR was achieved after 65 days. The time to achieve a steady state depends on many factors including type and characteristics of wastewater, HRT, inoculum source, volume of inoculations, configuration of $\mathrm{ABR}$, and operating temperature. So researchers have reported different times to achieve a steady state by ABR from 30 up to 175 days $(2,3,14,15,19,21)$. Based on the results presented in Table 1 and Figure 2, regarding the strength and temperature of wastewater, it could be claimed that in this study the strength of wastewater was weak and the reactors were operated at relatively low temperatures. The wastewater strength and temperature greatly affect the feasibility and performance of anaerobic treatment (2). Despite the advantages of anaerobic process, the results of many research have shown that conventional anaerobic systems, especially at low operating temperature, are not an appropriate technology for low-strength wastewater treatment $(3,10,12,15)$. At HRT=24 hours, after the start up and steady-state operation of ABR, the average removal efficiencies of BOD, COD, and TSS were achieved 71\%, $75 \%$, and $79 \%$, respectively. On day 130 and 165, the HRT was changed to 18 and 14 hours, respectively, and the performance of ABR was evaluated. As seen in Figure 4 with decreasing the HRT, the performance of $A B R$ is reduced. The average removal of $\mathrm{BOD}, \mathrm{COD}$ and TSS at HRT 24, 18 and 14 hours are shown in Figure 5. As can be seen, the average removal efficiency of TSS, BOD and COD at HRT $=18$ hours was $78.5,71$ and $72 \%$, and at $\mathrm{HRT}=14$ hours, it was $77.5,67$, and $68 \%$, respectively. Since for anaerobic biodegradability of organic materials, sufficient HRT, especially for methanogenic bacteria, is necessary, so with reducing HRT, the organic loading rate applied on the ABR was increased, which influenced the performance of the biomass activity and reduced the efficiency of ABR for BOD and COD removal. Also, with decreasing the HRT of ABR, the detention time for settling of TSS in different compartments of ABR was reduced, and subsequently, the performance of TSS removal was reduced. In Table 3, the performance of ABR obtained from this research is compared to other studies conducted on ABR. According to this table, different performances have been reported by researchers $(3,7,14,15,21,26)$, that could be related to different HRTs, characteristics of wastewater, configuration of $\mathrm{ABR}$, and the range of

Table 2. Effluent quality of ABR and SEABR and comparison with effluent discharge standards

\begin{tabular}{|c|c|c|c|c|c|c|c|c|c|c|c|c|}
\hline System & $\begin{array}{c}\text { COD } \\
\text { In }\end{array}$ & $\begin{array}{l}\text { COD } \\
\text { Out }\end{array}$ & $\begin{array}{c}\text { BOD } \\
\text { In }\end{array}$ & $\begin{array}{l}\text { BOD } \\
\text { Out }\end{array}$ & $\begin{array}{l}\text { TSS } \\
\text { In }\end{array}$ & $\begin{array}{l}\text { TSS } \\
\text { Out }\end{array}$ & $\begin{array}{c}\text { TKN } \\
\text { In }\end{array}$ & $\begin{array}{l}\text { TKN } \\
\text { out }\end{array}$ & $\begin{array}{l}\text { TP } \\
\text { In }\end{array}$ & $\begin{array}{l}\text { TP } \\
\text { out }\end{array}$ & $\begin{array}{l}\text { T. Coliform } \\
\text { MPN/100 mL }\end{array}$ & $\begin{array}{l}\text { T. Coliform } \\
\text { MPN/100mL }\end{array}$ \\
\hline ABR & 285 & 71 & 158 & 16 & 160 & 34 & 82 & 61 & 8 & 5.6 & $5 \times 10^{8}$ & $53 \times 10^{3}$ \\
\hline $\operatorname{ESABR}\left(0.78 \mathrm{~mA} / \mathrm{cm}^{2}\right)$ & 285 & 30 & 158 & 19 & 160 & 26 & 80 & 52 & 8 & 1.6 & $5 \times 10^{8}$ & 8000 \\
\hline Standards ${ }^{a}$ & -- & 60 & -- & 30 & -- & 40 & -- & -- & -- & 6 & --- & 1000 \\
\hline
\end{tabular}

Table 3. Performance comparison between some studies on various $A B R_{s}$ treating municipal or low strength wastewater (Removal \%)

\begin{tabular}{|c|c|c|c|c|c|c|}
\hline ABR system & HRT (h) & COD & TSS & TKN & TP & Reference \\
\hline ABR (modified) & 6 & 84 & 86 & -- & -- & 14 \\
\hline$A B R$ & 48 & 88 & 92 & -- & -- & 21 \\
\hline ABR (Bamboo carrier) & 48 & 79 & 81.9 & 19.2 & 30.8 & 15 \\
\hline$A B R$ & 12 & 43 & 83 & -- & -- & 3 \\
\hline$A B R$ & 22 & 72 & -- & -- & -- & 26 \\
\hline ABR (Hybride) & 36 & 89 & 94 & 15 & 26 & 7 \\
\hline$A B R$ & 24 & 77 & 80 & 23 & 30 & This research \\
\hline$A B R$ & 18 & 72 & 78.5 & 20 & 27 & This research \\
\hline$A B R$ & 14 & 68 & 77.5 & 18 & 25 & This research \\
\hline
\end{tabular}


Table 4. Percent removal of the main parameters by ABR and ESABR

\begin{tabular}{|c|c|c|c|c|c|c|}
\hline \multirow{2}{*}{ System } & \multicolumn{6}{|c|}{ Parameter } \\
\hline & BOD & COD & TSS & TKN & TP & LRV \\
\hline$A B R$ & $71 \pm 0.7$ & $75 \pm 0.8$ & $79.6 \pm 1$ & $23 \pm 2$ & $30.3 \pm 3$ & $5.7 \pm 0.1$ \\
\hline SEABR $\left(0.19 \mathrm{~mA} / \mathrm{cm}^{2)}\right.$ & $74.8 \pm 1$ & $79.4 \pm 1.2$ & $79.43 \pm 0.9$ & $26 \pm 2$ & $44.8 \pm 2.1$ & $6.2 \pm 0.3$ \\
\hline SEABR $\left(0.39 \mathrm{~mA} / \mathrm{cm}^{2)}\right.$ & $81.5 \pm 2.5$ & $85 \pm 1.5$ & $84 \pm 1$ & $29.3 \pm 3$ & $62 \pm 3.5$ & $6.5 \pm 0.7$ \\
\hline SEABR $\left(0.78 \mathrm{~mA} / \mathrm{cm}^{2}\right)$ & $87.8 \pm 1.3$ & $90 \pm 1$ & $83.6 \pm 0.9$ & $33.7 \pm 1$ & $79 \pm 3$ & $6.6 \pm 0.2$ \\
\hline SEABR $\left(1.15 \mathrm{~mA} / \mathrm{cm}^{2)}\right.$ & $58 \pm 14$ & $67.3 \pm 8.2$ & $60.75 \pm 9.7$ & $20 \pm 4$ & $50 \pm 6$ & $6.3 \pm 0.5$ \\
\hline
\end{tabular}

operating temperature.

From day 226, the ABR was operated as ESABR. Figure 7 shows the effect of electric current on the performance of the reactor. As shown in this figure, the percent removal of the BOD, COD, and TSS were increased by ESABR. Also, Figures 8 and 9 showed the increased removal of TKN, TP, and coliform bacteria by ESABR. In Table 4, the average efficiency of BOD, COD, TSS, TKN, TP, and coliform removal is compared between $\mathrm{ABR}$ and SEABR at HRT $=24 \mathrm{~h}$. As shown in Table 4, the performance of the SEABR was affected by the value of current density. By increasing the current density from 0.19 to $0.39 \mathrm{~mA} /$ $\mathrm{cm}^{2}$ and from 0.39 to $0.78 \mathrm{~mA} / \mathrm{cm}^{2}$, the performance of the reactor also increased, but by increasing the current density to $1.15 \mathrm{~mA} / \mathrm{cm}^{2}$, the performance was decreased. Improvement of the performance of biological reactor integrated with electrochemical process for treatment of wastewater or biogas production was reported by some studies by Aqaneghad et al (21), Heidrich et al (22), Yu et al (27), and Ran et al (28). In the present study, the best removal efficiency was achieved at current density of 0.78 $\mathrm{mA} / \mathrm{cm}^{2}$. In this current density, the removal efficiency of BOD, COD, TSS, TKN, and TP in ESABR were $16.8 \%$, $15 \%, 4 \%, 10.7 \%$, and $49 \%$ more than those obtained by ABR. Also, the LRV performance of SEABR for removal of coliform bacteria was about 1 Log greater than that obtained from ABR without electrical integration. So integration an electrochemical system with ABR could be a suitable technology for improving effluent quality. The performance improvement due to bio-electrochemical process could be attributed to two reasons. The first reason is that sacrificial anodes form metal precipitates, which improve the precipitation of contaminants due to flocs generation. Many studies have reported the potentials of electrocoagulation in treating a variety of wastewater including removal of suspended solids (2932). And the second one is that when electrical current flows the electrodes, reactor can act as an MEC. In this process, electrochemically active microorganisms are the dominant populations at the anode, which can accelerate degradation of organic compounds, and therefore, increase the COD removal (21,33-36).

As observed in Figures 7 to 9 and Table 4, with increasing current density from 0.78 to $1.15 \mathrm{~mA} / \mathrm{cm}^{2}$, the performance of the ESABR for removal of BOD, COD, TSS, TKN, and
TP were significantly decreased. With increasing current density to $1.15 \mathrm{~mA} / \mathrm{cm}^{2}$, disintegration of microbial flocs and biomass falling from electrodes was observed. It seems that with increasing the electrical current intensity, the electric current density has bacteriostatic or bactericidal effects on bacteria. Also, as a result of electrolysis, the active bacteriostatic or bactericidal substances such as $\mathrm{H}_{2} \mathrm{O}_{2}$, oxidizing radicals and chlorine, may be produced (37-39). The mechanism of antibacterial activity of electric current includes oxidation of enzymes and coenzymes, membrane damage, and bacterial respiratory rate (37). In terms of cost, the energy consumption of wastewater treatment systems is very important. The results of this study showed that the energy consumption of ESABR with the optimum performance was $0.41 \mathrm{kWh} / \mathrm{m}^{3}$. Although the energy consumption is in the average ranges of energy reported for activated sludge process in studies $(40,41)$, but in this system, the production of methane is an available energy sources that should be considered.

\section{Conclusion}

This study investigated the improved efficiency of electrical stimulation $\mathrm{ABR}$ and its applicability for treatment of municipal wastewater at low temperature. According to the results, the removal efficiency of contaminants enhanced by SEABR in comparison with ABR. The performance of SEABR was influenced by HRT and electric current density. In this study, At HRT of 24 hours and current density of $0.78 \mathrm{~mA} / \mathrm{cm}^{2}$, the best performance of SEABR was achieved. In this condition, the main parameters including BOD, COD, TSS, and TP in effluent met the effluent discharge standards to the surface water. Despite the significant reduction of total coliforms as an indicator bacterium, further removal is necessary to meet the standard. It should be noted that although this system uses electric power, but the consumption of energy by this system is much less than aerobic systems like activated sludge system that require electric energy for aeration and recirculation sludge, therefore, the ESABR is compatible with aerobic system for treatment of the municipal wastewater at an ambient temperature.

\section{Acknowledgements}

This work was extracted from a master's thesis and funded by the School of Public Health and Safety, Shahid Beheshti 
University of Medical Sciences, Tehran, Iran (Grant number: 11720). The authors would like to appreciate the Vice-Chancellor for Research and Technology of Shahid Beheshti University of Medical Sciences.

\section{Ethical issues}

The author hereby certify that all data collected during the research are as expressed in the manuscript, and no data from the study has been or will be published elsewhere separately.

\section{Competing interests}

The authors declare that they have no conflict of interests.

\section{Authors' contributions}

All authors contributed in data collection, analysis, and interpretation. All authors reviewed, refined, and approved the manuscript.

\section{References}

1. Aqanaghad M, Mousavi G, Ghanbari R. Anaerobic baffled reactor and hybrid anaerobic reactor performances evaluation in municipal wastewater treatment. Iranian Journal of Health, Safety and Environment 2017; 5(3): 1027-34.

2. Eddy M, Tchobanoglous G, Burton FL, Tsuchihashi R, Stensel HD. Wastewater Engineering: Treatment and Resource Recovery. 5th ed. New York: McGraw-Hill; 2014.

3. Hahn MJ, Figueroa LA. Pilot scale application of anaerobic baffled reactor for biologically enhanced primary treatment of raw municipal wastewater. Water Res 2015; 87: 494-502. doi: 10.1016/j.watres.2015.09.027.

4. Yu H, Anderson GK. Performance of a combined anaerobic reactor for municipal wastewater treatment at ambient temperature. Resour Conserv Recycl 1996; 17(4): 259-71. doi: 10.1016/0921-3449(96)01101-9.

5. Iza J, Colleran E, Paris JM, Wu WM. International workshop on anaerobic treatment technology for municipal and industrial wastewaters: summary paper. Water Sci Technol 1991; 24(8): 1-16. doi: 10.2166/wst.1991.0215.

6. van Haandel A, Kato MT, Cavalcanti PF, Florencio L. Anaerobic reactor design concepts for the treatment of domestic wastewater. Reviews in Environmental Science and Bio/Technology 2006; 5(1): 21-38. doi: 10.1007/ s11157-005-4888-y.

7. Barber WP, Stuckey DC. The use of the anaerobic baffled reactor (ABR) for wastewater treatment: a review. Water Res 1999; 33(7): 1559-78. doi: 10.1016/S0043-1354(98)00371-6.

8. Aiyuk S, Forrez I, Lieven de K, van Haandel A, Verstraete W. Anaerobic and complementary treatment of domestic sewage in regions with hot climates--a review. Bioresour Technol 2006; 97(17): 2225-41. doi: 10.1016/j. biortech.2005.05.015.

9. Alvarez JA, Armstrong E, Gomez M, Soto M. Anaerobic treatment of low-strength municipal wastewater by a two-stage pilot plant under psychrophilic conditions. Bioresour Technol 2008; 99(15): 7051-62. doi: 10.1016/j. biortech.2008.01.013.

10. Alvarez JA, Armstrong E, Presas J, Gomez M, Soto M.
Performance of a UASB-digester system treating domestic wastewater. Environ Technol 2004; 25(10): 1189-99. doi: 10.1080/09593332508618386.

11. Bandara W, Kindaichi T, Satoh H, Sasakawa M, Nakahara Y, Takahashi M, et al. Anaerobic treatment of municipal wastewater at ambient temperature: analysis of archaeal community structure and recovery of dissolved methane. Water Res 2012; 46(17): 5756-64. doi: 10.1016/j. watres.2012.07.061.

12. Chong S, Sen TK, Kayaalp A, Ang HM. The performance enhancements of upflow anaerobic sludge blanket (UASB) reactors for domestic sludge treatment--a state-of-the-art review. Water Res 2012; 46(11): 3434-70. doi: 10.1016/j. watres.2012.03.066.

13. Chu LB, Yang FL, Zhang XW. Anaerobic treatment of domestic wastewater in a membrane-coupled expended granular sludge bed (EGSB) reactor under moderate to low temperature. Process Biochem 2005; 40(3-4): 1063-70. doi: 10.1016/j.procbio.2004.03.010.

14. Bodkhe SY. A modified anaerobic baffled reactor for municipal wastewater treatment. J Environ Manage 2009; 90(8): 2488-93. doi: 10.1016/j.jenvman.2009.01.007.

15. Feng H, Hu L, Mahmood Q, Qiu C, Fang C, Shen D. Anaerobic domestic wastewater treatment with bamboo carrier anaerobic baffled reactor. Int Biodeterior Biodegradation 2008; 62(3): 232-8. doi: 10.1016/j. ibiod.2008.01.009.

16. Stuckey DC. Anaerobic Baffled Reactor (ABR) for Wastewater Treatment. In: Fang HH. Environmental Anaerobic Technology: Applications and New Developments. London: Imperial College Press; 2010:163-84.

17. Liu R, Tian Q, Chen J. The developments of anaerobic baffled reactor for wastewater treatment: a review. African Journal of Biotechnology 2010; 9(11): 1535-42. doi: $10.5897 / \mathrm{AJB} 10.036$.

18. Langenhoff AA, Stuckey DC. Treatment of dilute wastewater using an anaerobic baffled reactor: effect of low temperature. Water Res 2000; 34(15): 3867-75. doi: 10.1016/S0043-1354(00)00136-6.

19. Gopala Krishna GV, Kumar P, Kumar P. Treatment of lowstrength soluble wastewater using an anaerobic baffled reactor (ABR). J Environ Manage 2009; 90(1): 166-76. doi: 10.1016/j.jenvman.2007.08.017.

20. Reynaud N, Buckley CA. The anaerobic baffled reactor (ABR) treating communal wastewater under mesophilic conditions: a review. Water Sci Technol 2016; 73(3): 463-78. doi: $10.2166 /$ wst.2015.539.

21. Aqaneghad M, Moussavi G. Electrochemically enhancement of the anaerobic baffled reactor performance as an appropriate technology for treatment of municipal wastewater in developing countries. Sustain Environ Res 2016; 26(5): 203-8. doi: 10.1016/j.serj.2016.04.013.

22. Heidrich ES, Edwards SR, Dolfing J, Cotterill SE, Curtis TP. Performance of a pilot scale microbial electrolysis cell fed on domestic wastewater at ambient temperatures for a 12month period. Bioresour Technol 2014; 173: 87-95. doi: 10.1016/j.biortech.2014.09.083.

23. Cusick RD, Bryan B, Parker DS, Merrill MD, Mehanna M, Kiely PD, et al. Performance of a pilot-scale continuous flow microbial electrolysis cell fed winery wastewater. Appl Microbiol Biotechnol 2011; 89(6): 2053-63. doi: 10.1007/ 
s00253-011-3130-9.

24. Escapa A, Gil-Carrera L, Garcia V, Moran A. Performance of a continuous flow microbial electrolysis cell (MEC) fed with domestic wastewater. Bioresour Technol 2012; 117: 5562. doi: 10.1016/j.biortech.2012.04.060.

25. Eaton AD, Clesceri LS, Greenberg AE, Franson MAH. Standard methods for the examination of water and wastewater. Washington, DC: American Public Health Association, American Water Works Association, Water Environment Federation; 2017.

26. Foxon K, Pillay S, Lalbahadur T, Rodda N, Holder F, Buckley $\mathrm{CA}$. The anaerobic baffled reactor (ABR): an appropriate technology for on-site sanitation. Water SA 2004; 30(5): 4450. doi: 10.4314/wsa.v30i5.5165.

27. Yu Z, Leng X, Zhao S, Ji J, Zhou T, Khan A, et al. A review on the applications of microbial electrolysis cells in anaerobic digestion. Bioresour Technol 2018; 255: 340-8. doi: $\quad 10.1016 /$ j.biortech.2018.02.003.

28. Ran Z, Gefu Z, Kumar JA, Chaoxiang L, Xu H, Lin L. Hydrogen and methane production in a bioelectrochemical system assisted anaerobic baffled reactor. Int J Hydrogen Energy 2014; 39(25): 13498-504. doi: 10.1016/j.ijhydene.2014.02.086.

29. Phalakornkule C, Worachai W, Satitayut T. Characteristics of suspended solids removal by electrocoagulation. International Journal of Chemical and Molecular Engineering 2010; 4(5): 293-9.

30. Nawarkar CJ, Salkar VD. Solar powered Electrocoagulation system for municipal wastewater treatment. Fuel 2019; 237 : 222-6. doi: 10.1016/j.fuel.2018.09.140.

31. Devlin TR, Kowalski MS, Pagaduan E, Zhang X, Wei V, Oleszkiewicz JA. Electrocoagulation of wastewater using aluminum, iron, and magnesium electrodes. J Hazard Mater 2019; 368: 862-8. doi: 10.1016/j.jhazmat.2018.10.017.

32. Mollah MY, Morkovsky P, Gomes JA, Kesmez M, Parga J, Cocke DL. Fundamentals, present and future perspectives of electrocoagulation. J Hazard Mater 2004; 114(1-3): 199210. doi: 10.1016/j.jhazmat.2004.08.009.
33. Cui D, Guo YQ, Lee HS, Wu WM, Liang B, Wang AJ, et al. Enhanced decolorization of azo dye in a small pilotscale anaerobic baffled reactor coupled with biocatalyzed electrolysis system (ABR-BES): a design suitable for scalingup. Bioresour Technol 2014; 163: 254-61. doi: 10.1016/j. biortech.2014.03.165.

34. Hasany M, Mardanpour MM, Yaghmaei S. Biocatalysts in microbial electrolysis cells: a review. Int J Hydrogen Energy 2016; 41(3): 1477-93. doi: 10.1016/j.ijhydene.2015.10.097.

35. Liu H, Leng F, Guan Y, Yao Y, Li Y, Xu S. Simultaneous pollutant removal and electricity generation in a combined ABR-MFC-MEC system treating fecal wastewater. Water Air Soil Pollut 2017; 228(5): 179. doi: 10.1007/s11270-0173342-4.

36. Davis CP, Shirtliff ME, Trieff NM, Hoskins SL, Warren MM. Quantification, qualification, and microbial killing efficiencies of antimicrobial chlorine-based substances produced by iontophoresis. Antimicrob Agents Chemother 1994; 38(12): 2768-74. doi: 10.1128/aac.38.12.2768.

37. Huang X, Qu Y, Cid CA, Finke C, Hoffmann MR, Lim K, et al. Electrochemical disinfection of toilet wastewater using wastewater electrolysis cell. Water Res 2016; 92: 164-72. doi: 10.1016/j.watres.2016.01.040.

38. Kraft A. Electrochemical water disinfection: a short review. Platin Met Rev 2008; 52(3): 177-85. doi: $10.1595 / 147106708$ X329273.

39. Mizuta K, Shimada M. Benchmarking energy consumption in municipal wastewater treatment plants in Japan. Water Sci Technol 2010; 62(10): 2256-62. doi: 10.2166/ wst.2010.510.

40. Hernandez-Sancho F, Molinos-Senante M, Sala-Garrido R. Energy efficiency in Spanish wastewater treatment plants: a non-radial DEA approach. Sci Total Environ 2011; 409(14): 2693-9. doi: 10.1016/j.scitotenv.2011.04.018.

41. Molinos-Senante M, Sala-Garrido R, Iftimi A. Energy intensity modeling for wastewater treatment technologies. Sci Total Environ 2018; 630: 1565-72. doi: 10.1016/j. scitotenv.2018.02.327. 